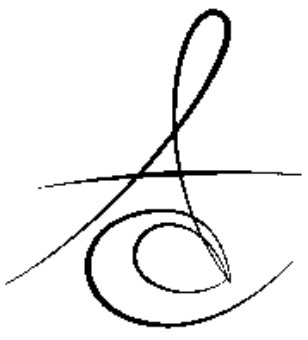

\title{
HEKİM ADAYLARININ AĞIZ-DİS SAĞLIĞI ALIŞKANLIKLARI VE BİLGİ DÜZEYLERİNİN DEĞERLENDİRİLMESİ
}

\section{THE EVALUATION OF ORAL AND DENTAL HEALTH HABITS AND KNOWLEDGE LEVELS OF THE MEDICAL STUDENTS}

\author{
Uzm. Dr. Ali ARIKAN* \\ Uzm. Dr. Serhat PİRİNÇCi' ${ }^{* * *}$ \\ Dr. Öğr. Üyesi Sultan KELEŞ ${ }^{* * * *}$
}

\author{
Dr. Öğr. Üyesi Gökhan ÖZKAN** \\ Prof. Dr. Filiz ABACIGİL ${ }^{* * * *}$ \\ Prof. Dr. PInar OKYAY ${ }^{* * * *}$
}

Makale Kodu/Article code: 3804

Makale Gönderilme tarihi: 24.07.2018

Kabul Tarihi: 12.12.2018

\section{öz}

Amaç: Genel sağlık sorunları ile ağız-diş sağlığı sorunlarının birbirlerini etkiliyor olması, hekimler ve diş hekimlerinin koruyucu yöntemler ve tedaviler açısından ortak çalışmasının önemini göstermektedir. Ülkemizde yüz bin kişiye düşen hekim sayısı 179 iken diş hekimi sayısı 32'dir. Bölgeler arasında bu fark daha da derinleşmektedir. Bu duruma bağı olarak ortaya çıkan genel ve ağız-diş sağlığı hizmet eşitsizliklerini gidermek için hekimlerin temel ve acil ağız-diş sağlığı bilgisi eğitimi almaları önemlidir. Tıp fakültesi eğitimi kapsamında, ağız-diş sağlığı ve ağız-diş sağlığının genel sağlık ile ilişkisi hakkında yeterli bir eğitimin mevcut olmadığı bilinmektedir. Bu çalışmanın amacı, son sınıfta okuyan tıp fakültesi öğrencilerinin ağız-diş sağlığı alışkanlıklarını belirlemek, bu konudaki bilgi düzeylerini ölçmek ve belirlenen eksikliklere çözüm önerileri sunmaktır.

Gereç ve Yöntem: Kesitsel nitelikte planlanan çalışma, Adnan Menderes Üniversitesi Tıp Fakültesi son sınıfta öğrenim gören $110(\% 85,9)$ öğrenci ile gerçekleştirildi. Öğrencilerin, hazırlanan 50 soruluk anketi, gözetim altında ve kendi kendilerine doldurmaları sağlandı. Elde edilen veriler, istatistiksel olarak değerlendirildi.

Bulgular: Öğrencilerin \%59,1'inin günde 2-3 kez, \%60'ının 2-3 dakika süre ile dişlerini fırçaladığı, $\% 56$ 'sının floridli diş macunu kullandığı ve \%43,1'inin diş macunun floridli olup olmadığını bilmediği belirlendi. Katıımcıların \%29,1'inin ilk kez diş hekimine 6 yaşından daha küçük iken \%21,8'inin ise 21 yaşından sonra gittiği, \%29,2'sinin son diş hekimi ziyaretine kontrol için gittiği ve \%76,6'sının son diş hekimi ziyaretinin üzerinden 6 aydan fazla süre geçtiği görüldü. Sorulan toplam 40 bilgi sorusundan doğru yanitlanan soru sayısı ortancası 20

Sonuç: Çalışmaya dahil edilen tıp fakültesi son sınıf öğrencilerinin ağız-diş sağlığı konusunda yeterli bilgi seviyesine sahip olmadıkları belirlendi. Hekimlerin ağız-diş sağlığı açısından bilgi seviyelerinin arttırılması için; tıp fakülteleri müfredatında ağız-diş sağlığı konusuna yer verilmesi, bu eğitimin standartlaştıııması, diş hekimliği fakülteleri ile bu konuda işbirliği yapılması gerektiği düşünülmektedir. Hekimlerin ağız-diş sağlığı yeterliliklerinin ve hizmet kalitesinin arttırılmasını da mümkün kılabilecektir. Anahtar Kelimeler: Ağız-diş sağığı, bilgi düzeyi, tıp fakültesi öğrencileri (min:1; maks: 34) bulundu. sağlanması, halk sağlığına yönelik eşitsizliklerin giderilmesini

\begin{abstract}
Aim: The interaction of general and oral and dental health problems demonstrates the importance of the collaboration of physicians and dentists in terms of preventive methods and treatments. In our country, the number of physicians per hundred thousand people is 179 , while the number of dentists is 32 . The difference is getting deeper between the regions.

It is important that physicians receive basic and urgent oral and dental health education in order to eliminate the general and oral and dental health inequalities associated with this condition. It is known that there is not enough education about oral and dental health and its relationship with general health in medical faculty. The aims of this study are to determine oral and dental health habits and to measure knowledge levels about this subject of medical students studying in the final year, and to present solutions to the deficiencies.
\end{abstract}

Material and Methods: The cross-sectional study was conducted among 110 (85.9\%) students studying in the last year of Medical Faculty of Adnan Menderes University. It was enabled that the students filled in a prepared 50-question survey themselves and under supervision. The data were evaluated statistically.

Results: It was determined that $59.1 \%$ of the students brushed their teeth 2-3 times a day, $60 \%$ brushed their teeth for 2-3 minutes, $56 \%$ used toothpaste with fluoride and $43.1 \%$ did not know whether toothpaste contains fluoride or not. Of the participants, $29.1 \%$ went to the dentist for the first time when they were younger than 6 years, while $21.8 \%$ went after 21 years of age, and $29.2 \%$ made their last dentist visit for check up, and $76.6 \%$ had more than 6 months since the last visit. The median of questions answered correctly among 40 information questions was 20 (min: 1, max: 34).

Conclusion: The final year students of the medical school included in the study did not have sufficient knowledge about oral and dental health. It is considered that to include the subject of oral and dental health in the curriculum of the medical faculties and to standardize this education and to collaborate with the faculties of dentistry are necessary to increase the knowledge level of physicians in terms of oral and dental health. Providing physicians's oral and dental health qualifications will enable elimination of inequalities related to the public health and improvement the quality of health services.

Keywords: Oral and dental health, knowledge level, medical students

${ }^{*}$ Nusaybin İlçe Sağlık Müdürlüğü

${ }^{* *}$ ADÜ Diş Hek. Fak. Ağız, Diş ve Çene Radyolojisi A.D.

${ }^{* * *}$ Urla Toplum Sağlığı Merkezi

****ADÜ Tıp Fak. Halk Sağlığı A.D.
${ }^{* * * *}$ ADÜ Diş Hek. Fak. Pedodonti A.D. 


\section{GİRIŞ}

Ağız diş-sağlığı ile ilgili problemler dünya çapında yaygın olarak görülmektedir. Özellikle Türkiye gibi gelişmekte olan ülkelerde diş çürüğü ve periodontal hastalıkların prevalansı halen oldukça yüksektir. ${ }^{1,2}$ Ağız-diş sağlığının genel sağlık ile yakından ilişkili olması, genel sağlığın iyi olması açısından önemli olup bu yakın ilişki, hekimler ve diş hekimlerinin koruyucu yöntemler ve tedaviler açısından birlikte çalışması gerekliliğini ortaya koymaktadır.

Ülkelerin genelinde, diş hekimlerine tıp hekimlerinden daha az başvurulduğu göz önünde tutulursa, özellikle kırsal kesimlerde ağız-diş sağlığı ile ilgili eğitimlerin sunulması, tıp hekimlerine düşebilmektedir. ${ }^{3,4}$ Ayrıca ağız-diş sağlığı problemlerine ilişkin tedavilerin yüksek maliyetli olması, nöbet sisteminin sınırlı düzeyde olması ve yeterli ekipman ve teknik gereksinimin kolaylıkla sağlanamaması nedeniyle hastalar ağız-diş sağlığı hizmetleri için acil servislere başvurabilmektedir. ${ }^{5}$ Bu nedenle tıp hekimlerinin ağız-diş sağlığı konusundaki donanımı, eğitim ve uygulama pratiğinde gerekli yardımı verebilmeleri önemlidir. Ancak, tıp fakültesi eğitim müfredatında, ağız-diş sağlığı ve ağız-diş sağlığının genel sağlık ile ilişkisine yönelik yeterli bir eğitim mevcut değildir., ${ }^{6,7}$ Bununla birlikte, hekimlerin ağız-diş sağlığı konusundaki bilgi düzeyleri ve kişisel ağız hijyeni alışkanlıkları, hastalara rol model olmada kritik bir yere sahiptir. ${ }^{8}$

$\mathrm{Bu}$ çalışmanın amacı, eğitiminin teorik müfredatını tamamlamış olan tıp fakültesi son sınıf öğrencilerinin ağız-diş sağlığı ile ilgili alışkanlıklarını belirlemek, bilgi düzeylerini ölçmek ve belirlenen eksiklikler ile ilgili çözüm önerileri sunmaktır.

\section{GEREÇ ve YÖNTEM}

Kesitsel planlanan bu çalışma için Adnan Menderes Üniversitesi Tıp Fakültesi Girişimsel Olmayan Klinik Araştırmalar Etik Kurulu'ndan izin alındı (2014/545 protokol numarası ile 12.02.2015 tarih ve 7 no'lu karar). Çalışmanın gerçekleştirilebilmesi için ise Adnan Menderes Üniversitesi Tıp Fakültesi Dekanlığı'ndan yazılı izin ve çalışma öncesinde her bir katılımcıya bilgi verilerek, katılımcıların sözlü onamları alındı.
Çalışma grubunu; Adnan Menderes Üniversitesi Tıp Fakültesi, 2014-2015 eğitim ve öğretim yılında, son sınıfta öğrenim gören tüm öğrenciler $(n=128)$ oluşturdu. Çalışmaya, katılmayı kabul eden öğrenciler dahil edilmiş olup son sınıf dışındaki sınıflarda okuyan, çalışmaya katılmak istemeyen, anket sorularını tamamen boş bırakan ve/veya anketi yarıda bırakan öğrenciler dahil edilmedi.

Mart-Nisan 2015 tarihleri arasında gerçekleştirilen anket uygulaması için katılımcılara bilgi verilip anket formu dağıtıldı ve gözetim altında, kendi kendilerine doldurmaları sağlandı. Üç bölümden oluşan 50 soruluk anket formunun; 1 . bölümünde katılımcıların sosyo-demografik özelliklerini belirlemek için dokuz soru (yaş, cinsiyet, medeni durum, sosyal güvence, aile ekonomik durumu, kişisel gelir, yaşadığı yer, anne ve baba eğitim durumu), 2.bölümde ağız-diş sağlığı ile ilgili tutum ve davranışlarını sorgulamak için 14 soru (diş fırçalama sıklık ve süresi, diş macununun florid özelliği, diş fırçası tipi ve değiştirme sıklığı, diş hekimi ziyaret zamanı ve sebebi, tütün ve alkol ürünleri kullanma sıklığı, bazı gıdaları tüketme sıklığı) ve 3. bölümde de ağız-diş sağlığı bilgi düzeylerini belirlemek için 27 soru (süt ve daimi dişlerin toplam sayısı ve sürme zamanı, diş fırçalamaya başlama yaşı, fırçalama ve fırça değiştirme sıklığı, kullanılan macun miktarı, ağız kokusuna neden olan faktörler ve yapılması gerekenler) soruldu.

Elde edilen veriler, SPSS 17 paket programı (IBM SPSS Inc., Chicago, USA) ile değerlendirildi. Tanımlayıcı istatistiklerde sayı ve yüzde dağılımlar gösterildi, ortalama \pm standart sapma değerleri verildi. Analitik analizlerde; kategorik değişkenlerin karşılaştırılmasında ki-kare, normal dağılıma uyan iki grup ölçüm değişkenlerinin karşılaştırılmasında student $\mathrm{t}$ testi kullanıldı. Tip 1 hata düzeyi $\mathrm{a}=0.05$ olarak alındı.

\section{BULGULAR}

Çalışmaya katılmayı kabul eden ve anketleri tamamlayan $110(\% 85,9)$ öğrencinin \%52,3'ü kız $(n=57), \% 47,7$ 'si erkek $(n=52)$ iken bir kişi cinsiyetini belirtmemiştir. Katılımcıların yaş ortancası 24 (min:22, maks:29) olup sadece 1 'i $(\% 0,9)$ evlidir. Öğrencilerin;

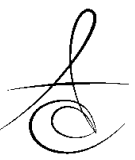


$\% 8,9$ 'unun $(n=9)$ herhangi bir sağlık güvencesinin olmadığı, \%68,2'sinin kişisel toplam aylık gelirinin 1000 TL'den az olduğu, \%9,2'sinin $(n=10)$ yurtta, $\% 24,5$ 'inin $(n=27)$ evde tek başına, \%52,7'sinin $(n=58)$ evde arkadaşları ile birlikte ve \%13,6'sının $(n=15)$ ailesi ile birlikte yaşadığı öğrenildi. En uzun süre yaşadıkları bölgeyi, öğrencilerin $\% 72,5^{\prime} i \quad(n=74)$ il, \%25,5'i $(n=26)$ ilçe, \%2'si $(n=2)$ köy olarak belirtti. Katılımcıların \% 34,3'ü $(n=37)$ herhangi bir tütün ürünü kullanırken, \%47,3'ü $(n=52)$ alkol tükettiğini, $\% 35,4$ 'ü ( $n=34)$ her gün sigara içtiğini ve \%45,6'sı $(n=41)$ herhangi bir dönemde nargile kullandığını ifade etti.

Öğrencilerin; \%59,1'inin günde 2-3 kez, \%60'ının 2-3 dakika süre ile dişlerini fırçaladığı, $\% 56$ 'sının floridli diş macunu kullandığı, \%43,1'inin diş macunun floridli olup olmadığını bilmediği, \%23,6'sının diş fırçasını 6 aydan fazla süre kullandığı veya hiç değiştirmediği, \%98'sinin standart tip diş fırçasını tercih ettiği bunu sırasıyla elektrikli $(n=9 ; \% 8,2)$, zaman göstergeli $(n=2 ; \% 1,8)$ ve diğer $(n=1 ; \% 0,9)$ tipte olanların takip ettiği belirlendi. Diş temizliğinde kullanılan araçlar değerlendirildiğinde; diş macununu her gün kullanan 105 kişi $(\% 95,5)$, kürdanı her gün kullanan 5 kişi $(\% 5,2)$, diş ipini her gün kullanan 4 kişi $(\% 4,1)$, misvağı her gün kullanan 1 kişi $(\% 1,0)$, diğer ürünleri (gargara vb.) her gün kullanan 9 kişi $(\% 8,2)$ olduğu görüldü. Öğrencilerin $\% 29,1^{\prime}$ inin $(n=32)$ ilk kez diş hekimine 6 yaşından daha küçük iken \%21,8'inin $(n=24)$ ise 21 yaşından sonra gittiği ve ilk diş hekimi ziyaretinin sıklıkla 7-12 yaş arasında olduğu anlaşıldı $(n=42 ; \% 38,2)$. Katılımcıların \%29,2'sinin son diş hekimi ziyaretine kontrol için gittiği ve \%76,6'sının son diş hekimi ziyaretinin üzerinden 6 aydan fazla süre geçtiği görüldü. Diş hekimine en son kontrol amaçlı gidenlerin sadece $\% 38,7^{\prime} \operatorname{sinin}(n=12)$, ziyaretinin üzerinden 6 aydan daha az süre geçtiği belirlendi (Tablo 1).

Çalışmaya katılan öğrencilerin bazı gıdaları tüketme sıklıkları, Tablo 2'de gösterilmektedir. Öğrencilerin çoğunluğunun çürüğe neden olabilecek gıdaları sıklıkla tükettikleri görüldü. Ağız-diş sağlığı ile ilgili karşılaşılan sorunlar, Tablo 3'te gösterilmektedir. Öğrencilerin, çoğunlukla, ağız-diş sağlığı ile ilgili sorunları ve bu sorunlara bağlı olarak oluşabilecek durumları yaşamadıkları belirlendi. Bununla birlikte, \%38,3'ünün diş fırçalarken kanama, \%36,4'ünün ağız kokusu, \% 33,6'sının gıdaları ısırmada zorlanma ve \%38,'ünün ağız-diş sağlığı problemlerinden dolayı gergin hissetme gibi problemler ile bazen karşılaştığı görüldü.

Öğrencilerin \%36,7'si bir hekim adayı olarak ağız-diş sağlığı bilgilerini yetersiz görürken, \%45'i kısmen yeterli ve \%18,3'ü yeterli görmekte idi. Ağızdiş sağlığı ile ilgili bilgi kaynağı sorusunda; öğrencilerin \%40'ı ( $n=48)$ örgün eğitim içerisinde, \%34,9'u ( $n=38)$ iletişim araçlarından, \%17,4'ü $(n=19)$ diş hekiminden ve $\% 3,7^{\prime}$ si $(n=4)$ de diğer kaynaklardan (aile, arkadaş) bilgi edindiğini bildirdi. Adnan Menderes Üniversitesi Tıp Fakültesi'nde bu konuda eğitim alan öğrenci bulunmadığı görüldü.

Öğrencilerin bilgi düzeyi sorularına verdiklerin yanıtların dağııımı Tablo 4'te gösterilmektedir. Toplam 40 bilgi sorusu içinden öğrencilerin doğru yanıtladıkları soru sayısı ortancasının 20 (min:1; mak: 34) olduğu bulundu. Öğrencilerden hiçbiri, ağız-diş sağlığı ile ilgili anatomi ve fizyoloji ve bebeklik ve çocukluk dönemi bilgi sorularının tamamına doğru cevap veremedi. Gebelik dönemi ile ilgili soruların tamamına doğru yanıt veren öğrenci sayısı sadece 3 kişi $(\% 2,8)$ iken ağız-diş sağlığı uygulamaları ile ilgili soruların tamamına doğru yanıt veren öğrenci sayısı 22 kişi $(\% 20,6)$ olarak bulundu. Gıdaların diş çürüğüne neden olup olmama durumuna göre yöneltilen soruların tamamına doğru yanıt veren öğrenci sayısı $27(\% 25,7)$, ağız kokusu etkeni sorularının tamamına doğru yanıt verenlerin sayısı $16(\% 15,1)$, ağız kokusunu engelleyen etkenlerin tümüne doğru yanıt verenlerin sayısı sadece $1(\% 0,9)$ kişi olarak belirlendi. Bilgi düzeyi soruları içinden; 'ilk olarak hangi daimi dişler sürer' sorusu en fazla yanlış cevap verilen soru olurken $(\% 95,5)$, dil fırçalamanın ağız kokusuna etkisi sorusu en fazla doğru cevap verilen soru oldu $(\% 93,6)$.

Kız öğrencilerin doğru yanıtladıkları soru sayısı ortancası 21 (min:10; maks: 34) iken erkek öğrencilerin ortancası 19 (min:1; mak: 29) olarak bulundu. Kız ve erkek öğrenciler arasındaki bu fark, istatistiksel olarak anlamlı değildi $(p=0,305)$. Ağız-diş sağlığı bilgilerinin yeterli olduğunu düşünen öğrencilerin doğru yanıtladıkları soru sayısı ortancası 21,5 (min:12; maks: 28), kısmen yeterli olduğunu düşünenlerin ortancası 21 (min:13; mak: 29) ve yeterli olmadığını düşünenlerin ortancası 18 (min:1; mak: 34) olarak belirlenmiş olup aralarındaki fark istatistiksel olarak anlamlıdır $(p=0,027)$.

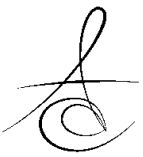


Atatürk Üniv. Diş Hek. Fak. Derg.

ARIKAN, ÖZKAN, PİRİNÇCI

J Dent Fac Atatürk Uni

ABACIGİL, KELES, OKYAY

Cilt:29, Sayı:2, Yıl: 2019, Sayfa, 189-196

Tablo 1. Araştırmaya katılan öğrencilerin diş hekimine gitme nedenleri ile ziyaretlerinin üzerinden geçen zamanın dağıımı

Son diş hekimi ziyareti üzerinden geçen zaman

6 aydan az 6-12 ay 13-24 ay 2 yıldan fazla Toplam

n (\%)

\begin{tabular}{|c|c|c|c|c|c|c|c|c|c|c|c|}
\hline & Kontrol & 12 & 38,7 & 6 & 19,4 & 5 & 16,1 & 8 & 25,8 & 31 & 29,2 \\
\hline & Diş ağrısı, abse & 7 & 17,1 & 12 & 29,3 & 10 & 24,4 & 12 & 29,3 & 41 & 38,7 \\
\hline & Dişeti kanaması & 2 & 25 & 4 & 50 & 1 & 12,5 & 1 & 12,5 & 8 & 7,6 \\
\hline & Dişlerde çapraşıklık & 3 & 37,5 & 1 & 12,5 & 0 & 0 & 4 & 50 & 8 & 7,6 \\
\hline Diş hekimi son ziyaret sebebi & Çene ve eklem problemleri & 0 & 0 & 1 & 20 & 2 & 40 & 2 & 40 & 5 & 4,7 \\
\hline & Travma & 1 & 25 & 3 & 75 & 0 & 0 & 0 & 0 & 4 & 3,7 \\
\hline & Diğer* & 0 & 0 & 4 & 44,4 & 2 & 22,2 & 3 & 33,3 & 9 & 8,5 \\
\hline & Toplam & 25 & 23,4 & 31 & 29,9 & 20 & 18,7 & 30 & 28 & 106 & 100 \\
\hline
\end{tabular}

*Diş çekimi, dolgu, diş taşı

Tablo 2. Araştırmaya katılan öğrencilerin bazı gıdaları tüketme sıklıklarının dağıımı

\begin{tabular}{|c|c|c|c|c|c|c|c|c|c|c|c|c|}
\hline & \multicolumn{2}{|c|}{ Günde birkaç kez } & \multicolumn{2}{|c|}{ Her gün } & \multicolumn{2}{|c|}{ Haftada birkaç kez } & \multicolumn{2}{|c|}{ Haftada bir kez } & \multicolumn{2}{|c|}{ Ayda birkaç kez } & \multicolumn{2}{|c|}{ Nadiren/Hiçbir zaman } \\
\hline Hazır meyve suyu $(n=110)$ & 8 & 7,3 & 23 & 20,9 & 46 & 41,8 & 10 & 9,1 & 16 & 14,5 & 7 & 6,4 \\
\hline $\begin{array}{l}\text { Tuzlu bisküvi-kek-çörek } \\
(\mathrm{n}=97)\end{array}$ & 5 & 4,5 & 22 & 20 & 62 & 56,4 & 8 & 7,3 & 12 & 10,9 & 1 & 0,9 \\
\hline $\begin{array}{l}\text { Tatlı bisküvi-kek-çörek } \\
(n=110)\end{array}$ & 5 & 4,5 & 17 & 15,5 & 67 & 60,9 & 9 & 8,2 & 11 & 10 & 1 & 0,9 \\
\hline Reçel-bal $(n=110)$ & 3 & 2,7 & 32 & 29,1 & 52 & 47,3 & 11 & 10 & 8 & 7,3 & 4 & 3,6 \\
\hline Tatlı-şeker $(n=110)$ & 10 & 9,1 & 26 & 23,6 & 45 & 40,9 & 19 & 17,3 & 8 & 7,3 & 2 & 1,8 \\
\hline Kola-limonata $(n=110)$ & 3 & 2,7 & 26 & 23,6 & 54 & 49,1 & 8 & 7,3 & 15 & 13,6 & 4 & 3,6 \\
\hline $\begin{array}{l}\text { Şekerli çay }(n=110) \\
\text { Şekerli kahve }(n=110)\end{array}$ & $\begin{array}{l}32 \\
15\end{array}$ & $\begin{array}{l}29,1 \\
13,6\end{array}$ & $\begin{array}{l}38 \\
31\end{array}$ & $\begin{array}{l}34,5 \\
28,2\end{array}$ & $\begin{array}{l}12 \\
27\end{array}$ & $\begin{array}{l}10,9 \\
24,5\end{array}$ & $\begin{array}{c}1 \\
10\end{array}$ & $\begin{array}{l}0,9 \\
9,1\end{array}$ & $\begin{array}{c}3 \\
10\end{array}$ & $\begin{array}{l}2,7 \\
9,1\end{array}$ & $\begin{array}{l}24 \\
17\end{array}$ & $\begin{array}{l}21,8 \\
15,5\end{array}$ \\
\hline Şekersiz sakız (n=109) & 8 & 7,3 & 13 & 11,9 & 40 & 36,7 & 14 & 12,8 & 17 & 15,6 & 17 & 15,6 \\
\hline Süt ve süt ürünleri $(\mathrm{n}=110)$ & 12 & 10,9 & 36 & 32,7 & 37 & 33,6 & 10 & 9,1 & 13 & 11,8 & 2 & 1,8 \\
\hline
\end{tabular}

Tablo 3. Araştırmaya katılan öğrencilerin son 12 ay içerisinde ağız-diş sağlığı ile ilgili karşılaştıkları sorunların dağıımı

\begin{tabular}{|c|c|c|c|c|c|c|c|c|c|c|}
\hline \multirow[b]{2}{*}{ Gıdaları ısırmada zorluk $(n=107)$} & \multicolumn{2}{|c|}{ Çok Sık } & \multicolumn{2}{|c|}{$\begin{array}{l}\text { Oldukça Sık } \\
\text { n (\%) }\end{array}$} & \multicolumn{2}{|c|}{ Bazen } & \multicolumn{2}{|c|}{ Olmadı } & \multicolumn{2}{|c|}{ Bilmiyorum } \\
\hline & 1 & 0,9 & 0 & 0 & 36 & 33,6 & 68 & 63,6 & 2 & 1,9 \\
\hline Gıdaları çiğnemede zorluk $(n=107)$ & 0 & 0 & 1 & 0,9 & 31 & 29 & 73 & 68,2 & 2 & 1,9 \\
\hline Konuşma zorluğu $(n=107)$ & 0 & 0 & 1 & 0,9 & 9 & 8,4 & 95 & 88,8 & 2 & 1,9 \\
\hline Ağız kokusu $(n=107)$ & 2 & 1,8 & 8 & 7,5 & 39 & 36,4 & 54 & 50,5 & 4 & 3,7 \\
\hline Diş fırçalarken kanama $(n=107)$ & 3 & 2,8 & 18 & 16,8 & 41 & 38,3 & 43 & 40,2 & 2 & 1,9 \\
\hline Diş/dişeti rahatsızlıklarından dolayı klinikte çalışamama $(n=107)$ & 1 & 0,9 & 1 & 0,9 & 11 & 10,3 & 91 & 85,0 & 3 & 2,8 \\
\hline Diş hekimi korkusu $(n=107)$ & 4 & 3,7 & 16 & 15 & 23 & 21,5 & 63 & 58,9 & 1 & 0,9 \\
\hline Dişlerin görüntüsünden utanma $(n=106)$ & 1 & 0,9 & 8 & 7,5 & 29 & 27,4 & 66 & 62,5 & 2 & 1,9 \\
\hline Ağız-diş sağlığı problemlerinden dolayı gergin hissetme $(n=107)$ & 1 & 0,9 & 5 & 4,7 & 41 & 38,3 & 58 & 54,2 & 2 & 1,9 \\
\hline Diş görüntüsünden dolayı gülümsemekten kaçınma (n=107) & 2 & 1,9 & 3 & 2,8 & 17 & 15,9 & 82 & 76,6 & 3 & 2,8 \\
\hline Daha az hoşgörülü hissetme $(n=106)$ & 1 & 0,9 & 4 & 3,8 & 18 & 17 & 78 & 73,6 & 5 & 4,7 \\
\hline Sosyal etkinliklere katılımın azalması $(n=107)$ & 1 & 0,9 & 2 & 1,9 & 24 & 22,4 & 76 & 71 & 4 & 3,7 \\
\hline Uykunun sık sık kesintiye uğraması $(n=107)$ & 2 & 1,9 & 3 & 2,8 & 17 & 15,9 & 82 & 76,6 & 3 & 2,8 \\
\hline
\end{tabular}


Tablo 4. Araştırmaya katılan öğrencilerin, bilgi düzeyi sorularına verdikleri doğru yanıtlara göre dağııımı

\begin{tabular}{|c|c|c|}
\hline & \multicolumn{2}{|c|}{ Doğru yanıt } \\
\hline & $\mathbf{n}$ & $\%$ \\
\hline & \multicolumn{2}{|c|}{ A. Anatomi ve Fizyoloji Bilgi Soruları } \\
\hline Süt dişlerinin toplam sayısı nedir? $(\mathrm{n}=108)$ & 26 & 24,1 \\
\hline Süt dișleri ne zaman sürmeye bașlar? $(n=108)$ & 49 & 45,4 \\
\hline Daimi dişler kaç yaşında sürmeye başlar? $(n=108)$ & 42 & 38,9 \\
\hline İlk olarak hangi daimi dişler sürer? $(n=110)$ & 5 & 4,5 \\
\hline Daimi dişlerin toplam sayısı nedir? $(n=109)$ & 85 & 78 \\
\hline Tüm sorulara doğru yanıt verenler ( $n=107)$ & 0 & 0 \\
\hline \multicolumn{3}{|l|}{$\begin{array}{l}\text { B. Bebeklik ve Cocukluk Dönemine ait Bilgi } \\
\text { Soruları }\end{array}$} \\
\hline $\begin{array}{l}\text { Bebek ve çocuklarda ağız ve diş temizliği ne zaman } \\
\text { başlamalıdır? }(n=110)\end{array}$ & 42 & 38,2 \\
\hline $\begin{array}{l}\text { Çocuklarda diş fırçalamaya kaç yaşına kadar ebeveyn } \\
\text { eşlik etmelidir? }(n=110)\end{array}$ & 52 & 47,3 \\
\hline $\begin{array}{l}0-3 \text { yaş grubu çocuklarda diş fırçalama sırasında ne kadar } \\
\text { diş macunu kullanılımalıdır? }(\mathrm{n}=110)\end{array}$ & 26 & 23,6 \\
\hline $\begin{array}{l}\text { 3-6 yaş grubu çocuklarda ne kadar diş macunu } \\
\text { kullanımalıdır? }(n=110)\end{array}$ & 60 & 54,5 \\
\hline Süt dişleri çürüdüğünde ne yapılmalıdır? (n=110) & 54 & 49,1 \\
\hline $\begin{array}{l}\text { Ağız-diş sağlığı açısından, gece ağlayarak uyanan bir } \\
\text { bebeğe biberonla verilebilecek en uygun içecek nedir? } \\
(n=109)\end{array}$ & 31 & 28,4 \\
\hline $\begin{array}{l}\text { Tüm sorulara doğru yanıt verenler }(n=109) \\
\text { C. Gebelik Dönemi ile İlgili Bilgi Soruları }\end{array}$ & C. Gebelik Dönemi ile İlgili Bilgi Soruları & 0 \\
\hline $\begin{array}{l}\text { Bebek, anne karnındaki gelişimi sırasında, yeterli kalsiyum } \\
\text { desteği bulamadığı takdirde annenin dişlerindeki } \\
\text { kalsiyumu kullanır. }(n=109)\end{array}$ & 20 & 18,3 \\
\hline $\begin{array}{l}\text { Hamilelik dönemi boyunca, kadınların dişeti hastalıklarına } \\
\text { karşı eğilimleri artar. }(n=109)\end{array}$ & 86 & 78,9 \\
\hline $\begin{array}{l}\text { Emzirme sırasında kadınların diş çürüklerine karşı } \\
\text { eğilimleri artar. }(n=109)\end{array}$ & 9 & 8,3 \\
\hline $\begin{array}{l}\text { Gebelikte kullanılan bazı antibiyotikler çocukta diş } \\
\text { lekelenmelerine neden olabilir. }(n=109)\end{array}$ & 81 & 74,3 \\
\hline $\begin{array}{l}\text { Gebelikte kullanılan antibiyotikler annede diş kaybına } \\
\text { neden olur. }(n=109)\end{array}$ & 21 & 19,3 \\
\hline & 3 & 2,8 \\
\hline \multicolumn{3}{|l|}{$\begin{array}{l}\text { D. Ağız-Dis Sağlığı Uygulamaları ile İlgili Bilgi } \\
\text { Soruları }\end{array}$} \\
\hline Diş firçalama süresi ne kadar olmalıdır? ( $n=110)$ & 70 & 63,6 \\
\hline Dişler hangi sıklıkla fırçalanmalıdır? $(n=109)$ & 98 & 89,9 \\
\hline Diş macununda florid olmalı mıdır? $(n=110)$ & 66 & 60 \\
\hline $\begin{array}{l}\text { Kontrol amaçlı rutin diş hekimi ziyareti hangi sıklıkla } \\
\text { yapılmalıdır? }(n=108)\end{array}$ & 63 & 58,3 \\
\hline Diş fırçası ne sıklıkla değiştirilmelidir? $(n=108)$ & 62 & 57,4 \\
\hline $\begin{array}{l}\text { Tüm sorulara doğru yanıt verenler }(n=107) \\
\text { E. Diğer Sorular }\end{array}$ & 22 & 20,6 \\
\hline \multicolumn{3}{|l|}{$\begin{array}{l}\text { Aşağıdaki yiyeceklerden hangisi/hangileri ara öğünlerde } \\
\text { diş çürüklerine uygun bir ortam hazırlar? }\end{array}$} \\
\hline Muhallebi & 81 & 76,4 \\
\hline Kola, meşrubat vb. içecekler & 102 & 92,7 \\
\hline Reçel & 89 & 81,7 \\
\hline Bal & 81 & 73,6 \\
\hline Dondurma & 89 & 82,4 \\
\hline Havuc & 68 & 63 \\
\hline Peynir & 58 & 53,7 \\
\hline Tüm sorulara doğru yanıt verenler $(n=105)$ & 27 & 25,7 \\
\hline \multicolumn{3}{|l|}{$\begin{array}{l}\text { Aşağıdakilerden hangisi/hangileri halitozise (ağız kokusu) } \\
\text { neden olmaz? }\end{array}$} \\
\hline Dil üzerindeki artıklar & 26 & 24,1 \\
\hline Takma dişler & 23 & 21,5 \\
\hline Derin çürükler & 26 & 24,1 \\
\hline Ağızdaki tümoral oluşumlar & 26 & 24,3 \\
\hline Sebze ağırlıklı gıdalar ile beslenme & 37 & 33,9 \\
\hline Tüm sorulara doğru yanıt verenler $(n=106)$ & 16 & 15,1 \\
\hline \multicolumn{3}{|l|}{ Ağız kokusunu engellemek için hangileri yapılabilir? } \\
\hline Dil fırçalama & 103 & 93,6 \\
\hline Proteinli gıdalar ile beslenme & 12 & 10,9 \\
\hline Probiyotik içeren besinlerin kullanımı & 63 & 57,8 \\
\hline Ağızdaki tüm dolguların yenilenmesi & 9 & 8,2 \\
\hline Gastrointestinal sistem hastalıklarının elimine edilmesi & 96 & 87,3 \\
\hline Tüm sorulara doğru yanıt verenler $(n=109)$ & 1 & 0,9 \\
\hline $\begin{array}{l}\text { Diş çürüğü oluşumunda en etkili mikroorganizma } \\
\text { hangisidir? ( } n=109)\end{array}$ & 45 & 41,7 \\
\hline $\begin{array}{l}\text { Diş dostu (çürüğe neden olmaz) logosunu tanıyabilme } \\
\text { durumu }\end{array}$ & 36 & 33,3 \\
\hline
\end{tabular}

\section{TARTIŞMA}

Ülkemiz 2015 yılı Sağık Bakanlığı verilerine göre, yüz bin kişiye düşen hekim sayısı 179, pratisyen hekim sayısı 53 iken diş hekimi sayısı 32'dir. Bölgelere göre inceleme yapıldığında, bu farklılık daha da artmakta, yüz bin kişiye düşen hekim sayısı $131^{\prime} \mathrm{e}$, diş hekimi sayısı 14'e düşebilmektedir. Bununla birlikte, hekimlerin sadece \%20'si özel sektörde çalışırken, diş hekimlerinde bu oran \%57,6'ya çıkmaktadır. Özel sektörde sunulan diş hekimliği hizmetleri, Sosyal Güvenlik Kurumu tarafından karşılanmamakta olup bu durum hastaların tedavilerini ertelemelerine neden olabilmektedir. ${ }^{9}$ Diş hekimlerine, ağız-diş sağlığının yaygınlaştırılmasında destek verebilecek en yakın insan kaynağı olan hekimlerin ağız-diş sağlığı konusunda donanım kazanmış olmaları önemlidir. Bu çalışmanın sonuçları, söz konusu eşitsizliğin giderilmesinde yapılabilecekler açısından bir durum tespiti sağlamaktadır.

Tıp fakültesinde eğitim alan öğrencilerin ağız-diş sağlığı ile ilgili yaklaşımlarını ve bu konudaki bilgi düzeylerini ölçmeyi amaçlayan bu çalışmada yer alan 110 öğrencinin sonuçları, eksikliklerin boyutunu göstermektedir. Çalışma bulgularımıza göre, öğrencilerin yarıdan fazlası dişlerini yeterli sayı ve sürede fırçaladığı halde diş ipi kullanmamaktadır. Naseem ve ark., ${ }^{10}$ çalışmalarında, tıp fakültesi öğrencilerinin \%55, 9 'unun günde iki kez, \%36,7'sinin ise günde yalnızca bir kez diş fırçaladıklarını bildirmişlerdir. Ülkemizde yürütülen diğer bir çalışmada, çalışma bulgularımız ile benzer sonuçlar elde edilmiş, tıp fakültesi öğrencilerinin günde en az bir kez düzenli diş fırçalama oranı $\% 88$, düzenli diş ipi kullanımı oranı $\% 4$ olarak bildirilmiştir. ${ }^{11}$ Çalışmamıza katılan öğrencilerin 1/3'ünden azının son diş hekimi ziyareti kontrol amaçlı iken genellikle ağrı şikâyeti ile başvurulduğu ve katılımcıların \%76,6'sının son diş hekimi ziyaretinin üzerinden 6 ay geçtiği görülmektedir. Benzer şekilde, Hindistan'da yürütülen bir çalışmada, tıp fakültesi öğrencilerinin \%53'ünün ancak bir şikâyet varlığında diş hekimine gittikleri bildirilmiştir. ${ }^{12}$ Oyetela ve ark.'nın ${ }^{13}$ yürüttüğü çalışmada da tıp fakültesi öğrencilerinin ancak \%33'ünün diş hekimi ziyaretinde bulunduğu belirtilmiştir. Erdoğan ve ark.'nın ${ }^{11}$ çalışmasında, tıp fakültesi öğrencilerinin hiç diş hekimine gitmeme oranı \%6,6, son bir yıl içinde diş hekimine gitme oranı ise $\% 57$ olarak belirtilmiştir. Çalışma sonuçları, tıp fakültesi öğrencilerinin ağız-diş

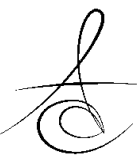


sağlığı ile ilgili tutumlarının yetersiz olduğunu ve bu bilinci topluma aktarabilecek sağlık çalışanlarından biri olan hekimlerin bu konuda eğitim almalarının gerekliliğini göstermektedir.

Öğrencilere ağız-diş sağlığı ile ilgili bilgi düzeyleri hakkında yöneltilen soruda katılımcıların \%18,3'ü kendilerini yeterli görmüşlerdir. Gill ve ark.'nın ${ }^{14}$ çalışmasında, öğrenciler kendilerini \%23 oranında yeterli görmüşlerdir. Çalışkan ve ark.'nın ${ }^{15}$ yaptığı çalışmaya göre, çalışmaya katılan tıp fakültesi 5. sınıf öğrencilerinin sadece $\% 11,7^{\prime}$ si ağız-diş sağlığı ile ilgili görev ve sorumlulukları yerine getirmek için bilgi ve becerilerini yeterli bulmuşlardır. Çalışmamızda kendilerini bilgi düzeyi olarak yeterli gören öğrenciler, kendilerine yöneltilen toplam 40 soruyu 21,5 ortanca ile cevaplamışlardır. Yetersiz olduklarını düşünen öğrencilerin ortancası 18 bulunmuş olup, aradaki istatistiksel fark, öğrencilerin aslında eksikliklerinin farkında oldukları verisi ile uyumludur. Bütün sorulara verilen doğru yanıt sayısında kız ve erkek öğrenciler arasında istatistiksel bir fark bulunmamıştır. Türkiye'de yürütülen diğer çalışmalarda, ${ }^{4,15,16}$ cinsiyetler arasında, verilen doğru yanıtlara ilişkin bir değerlendirme bulunamamıştır.

Öğrencilerden ağız-diş sağlığı ile ilgili anatomi ve fizyoloji bilgi sorularının tamamına doğru cevap veren olmamıştır. Bu sorulardan süt dişlerinin sürme zamanını, her iki öğrenciden biri $(\% 54,6)$ doğru yanıtlayamamıştır. Bu oran, Kılınç ve ark. ${ }^{4}$ (\%62) ile Çalışkan ve ark.'nın ${ }^{16}$ (\%61) sunduğu sonuçlara göre daha düşüktür. Süt dişlerinin toplam sayısı sorusuna ise çalışmamızda \%24,1 oranında doğru yanıt verilmiştir. Kılınç ve ark.'nın ${ }^{4}$ çalışmasında bu oran $\% 81$ iken Çalışkan ve ark.'nın ${ }^{16}$ çalışmasında \%47 olarak belirtilmiştir. Süt dişleri, bebeklik dönemi gelişiminin önemli izlem parametrelerinden biridir. Bu konuda gözlenen bilgi eksikliği, sağlıklı bebek/çocuk rutin izlem kalitesi açısından da önemli bir eksikliktir.

Bebeklik ve çocukluk dönemi bilgi sorularının da tamamını doğru yanıtlayan öğrenci bulunmamaktadır. Gebelik dönemi ile ilgili soruların tamamına doğru yanıt veren öğrenci sayısı ise yalnızca 3 kişi $(\% 2,8)$ olarak belirlenmiştir. Bu oranlar, ağız-diş sağlığı uygulamaları ile ilgili sorularda artmış ve soruların tamamına doğru yanıt veren öğrenci sayısı 22 kişi $(\% 20,6)$ olarak bulunmuştur. Diş fırçalama süresi ve dişlerin fırçalanma sıklığı gibi uygulama sorularında öğrencilerin daha etkin yanıt verebildiği görülmüştür. Bilgi düzeyi soruları içinden 'İlk olarak hangi daimi dişler sürer?' sorusu \%95,5 oran ile en fazla yanlış cevap verilen soru olmuştur. Bu temel soruda verilen yanlış oran yüzdesinin yüksek olması, tıp fakültesi müfredatında, bu konuların da yer alması gerektiği düşüncesini doğrular niteliktedir. Ahmad ve ark. ${ }^{17}$ da benzer şekilde, Avustralya ve Malezya'da tıp fakültesi müfredatında ağız-diş sağlığı vurgusunun yetersiz olduğunu rapor etmişlerdir. Rodakowska ve ark. ${ }^{18}$ İskandinav ve Polonyalı tıp fakültesi öğrencilerini karşılaştırdıkları çalışmalarında, İskandinav öğrencilerin ağız sağlığı ile ilgili bilgi düzeylerinin daha yüksek olduğunu bildirmişlerdir. Nicely ve ark., ${ }^{19}$ geniş kapsamlı ağız-diş sağlığı müfredatının tıp fakültesi öğrencilerinde olumlu gelişim sağlayabileceğini belirtmişlerdir. Abbott ve ark. ${ }^{20}$ da temel ağız sağlığı eğitiminin tıp fakültesi müfredatında yer almasının oldukça önemli olduğunu vurgulamışlardır. Kumar ve ark. $^{21}$ tıp ve diş hekimliği fakültesi öğrencilerini karşılaştırdıkları çalışmalarında, diş hekimliği fakültesi öğrencilerinin ağız sağlığı ile ilgili bilgi düzeyleri daha yüksek olmasına rağmen, bu konudaki eğitimlere daha fazla zaman ayrılması gerektiğini belirtmişlerdir. Park ve ark. ${ }^{22}$ ağız sağığı ile ilgili eğitim verilen tıp fakültesi öğrencilerinin farkındalık düzeylerinin, eğitim sonrasında belirgin bir şekilde artış gösterdiğini rapor etmişlerdir.

Halitozis, son dönemlerde tıp ve diş hekimliği alanlarında önemi giderek artan konular arasında yer almaktadır. Dil fırçalamanın ağız kokusuna etkisi sorusu, bu grupta en yüksek yüzde $(\% 93,6)$ ile doğru cevaplanan soru olmuştur. Ancak, ağız kokusunun giderilmesi için ağızdaki tüm dolguların yenilenmesi gerektiği yanılgısına düşen öğrencilerin yüzdesinin 91,8 düzeyinde olması da dikkat çekicidir. Bu anlamda ağız kokusu, gastrointestinal problemler ve beslenme şekli gibi faktörlerden de etkilenmesi nedeniyle teşhis ve ayırıcı tanı yönünden hem diş hem de tıp hekimlerini yakından ilgilendirmektedir. Bu konudaki eksikliğin giderilebilmesi için de halitozis konusuna her iki fakültenin müfredatında geniş yer verilmelidir. Zhang ve ark.'nın ${ }^{6}$ yaptıkları çalışmada, tıp ve diş hekimlerinin işbirliği içinde çalışmalarının genel vücut sağlığı açısından oldukça önemli olduğu vurgulanmıştır.

Çalışmamıza katılan öğrencilerin beslenme alışkanlıkları değerlendirildiğinde, öğrencilerin çoğunluğunun en azından haftada birkaç kez ağız-diş sağığını olumsuz etkileyecek şekerli gıdaları sıklıkla tükettikleri 
görülmüştür. Bu bağlamda, hekim adaylarında sağlığın geliştirilmesi kavramının içselleştirilmesi için diş sağlığının aracı olarak kullanıması düşünülebilir.

Adnan Menderes Üniversitesi Tıp Fakültesi müfredatında ağız-diş sağlığı ile ilgili herhangi bir eğitim yer almamaktadır. Ülkemizde yapılan benzer çalışmalarda, ${ }^{4,15}$ Dokuz Eylül Üniversitesi Tıp Fakültesi son sınıf öğrencilerinin tamamı ve Ankara Üniversitesi Tıp Fakültesi 5. sınıf öğrencilerinin \%94'ü müfredatlarında ağız-diş sağlığı eğitiminin yer almadığını belirtmişlerdir. Bu konuda gerçekleştirilen önemli bir adım, 2014 yılında tıp fakülteleri için tekrar düzenlenen Ulusal Çekirdek Eğitim Programı'nda ağız-diş sağlığı konusunun program içerisine dahil edilmesi olmuştur. Bununla birlikte, ülkemizde yürütülen diğer bir çalışmada, tıp ve diş hekimliği fakültesi öğrencileri karşılaştırımış, tıp fakültesi öğrencilerinin ağız-diş sağlığı ile ilgili temel konularda yetersiz olduğu vurgulanmıştı. ${ }^{23}$

\section{SONUÇ}

Hekim adaylarının ağız-diş sağlığı ile ilgili bilgileri yetersiz olup tutum ve davranışları eksiklikler içermektedir. Hekimlerin ağız-diş sağığı açısından bilgi seviyelerinin arttıııması için; tıp fakülteleri müfredatında ağız-diş sağlığı konusuna yer verilmesi, bu eğitimin standartlaştırıması, diş hekimliği fakülteleri ile bu konuda işbirliği yapılması gerektiği düşünülmektedir. Hekimlerin ağız-diş sağığı yeterliliklerinin sağlanması, halk sağlığına yönelik eşitsizliklerin giderilmesini ve hizmet kalitesinin arttırımasını mümkün kılabilecektir.

Ali Arıkan: ORCID ID: 0000-0002-5844-6094 Gökhan Özkan: ORCID ID: 0000-0003-4822-7303 Serhat Pirinççi: ORCID ID: 0000-0002-6024-5443 Filiz Abacıgil: ORCID ID: 0000-0003-4291-0013 Sultan Keleş: ORCID ID: 0000-0001-7978-8715 PInar Okyay: ORCID ID: 0000-0002-3565-1490

\section{KAYNAKLAR}

1. Gökalp S, Doğan BG. Erişkin ve yaşılılarda ağız diş sağığı profili Türkiye 2004. Hacettepe Diş Hek Fak Derg 2007;31:11-8.

2. Alkan A. Diş hekimleri ve diş hekimliği öğrencilerinin oral hijyen eğitimi hakkındaki görüş ve uygulamaları. Atatürk Üniv Diş Hek Fak Derg 2003;13:4-8.
3. Al-Omiri MK, Barghout $\mathrm{NH}$, Shaweesh AI, Malkawi Z. Level of education and gender-specific selfreported oral health behavior among dental students. Oral Health Prev Dent 2012;10:29-35.

4. Kılınç G, Gülay T. Dokuz Eylül Üniversitesi Tıp Fakültesi son sınıf öğrencilerinin ağız diş sağlığı konusundaki bilgi düzeyleri. DEÜ Tıp Fakültesi Dergisi 2010;24:131-7.

5. Verma S, Chambers I. Dental emergencies presenting to a general hospital emergency department in Hobart, Australia. Aust Dent J 2014;59:329-33.

6. Zhang S, Lo EC, Chu CH. Attitude and awareness of medical and dental students towards collaboration between medical and dental practice in Hong Kong. BMC Oral Health 2015;15:53.

7. Ramirez J, Arce R, Contreras A. Why must physicians know about oral diseases? Teach Learn Med 2010;22:148-55.

8. Halboub ES, Al-Maweri SA, Al-Jamaei AA, AlWesabi MA, Shamala A, Al-Kamel A, Alsharani A, Eissa N. Self-reported oral health attitudes and behavior of dental and medical students, Yemen. Glob J Health Sci 2016;8:56676.

9. T.C. Sağlık Bakanlığı Sağlık İstatistikleri Yıllığı 2015. Türkiye Cumhuriyeti Sağlık Bakanlığı Sağlık Araştırmaları Genel Müdürlüğü, 2016 http://www.saglikistatistikleri.gov.tr/dosyalar/SIY 2015.pdf (18 Eylül 2018 tarihinde ulaşıldı.).

10.Naseem S, Fatima SH, Ghazanfar H, Haq S, Khan NA, Mehmood M, Ghazanfar A. Oral hygiene practices and teeth cleaning techniques among medical students. Cureus 2017;9:e1487.

11.Erdoğan A, Bozkurt Aİ, Ergin A, Topaloğlu $S$, Aydın A, Arslan A, Avcl A, Kurtcephe B, Er F, Çevik İ, Karagöz K, Kahyaoğlu M. Pamukkale Üniversitesi Tıp Fakültesi öğrencilerinde ağız-diş sağlığının değerlendirilmesi. Pam Med J 2015;8:1-9.

12.Jacob S, Saify M, Jain DK, Paiwal K. Self-assessed oral health awareness and attitude of the first and final year undergraduate medical and dental students in India. J Orofac Res 2014;4:25-9.

13. Oyetela EO, Oyewole T, Adedigba M, Aregbesola ST, Umezudike K, Adewela A. Knowledge and awareness of medical doctors, medical students and nursesabout dentistry in Nigeria. Pan Afr Med ] 2016;23:172. 
14.Gill Y, Scully C, Attitudes and awareness of final year predoctoral dental and medical students to medical problems in dentistry. J Dent Educ 2006;70:991-5.

15.Çalışkan D, Yaşar F, Demirören M, Tunçbilek A. Tıp Fakültesi 5. dönem öğrencilerinin birinci basamak sağlık hizmetlerinde hekimin ağız ve diş sağlığı ile ilgili görev ve sorumlulukları konusunda görüşleri. TED 2005;19;8-13.

16.Çalışkan D, Yaşar F, Tunçbilek A. A.Ü.T.F. 9-10 sömestr öğrencilerinin ağız diş sağlığı konusunda bilgi düzeyleri. Ankara Üniv Tıp Fak Mecm 2002;55:137-42.

17.Ahmad MS, Abuzar MA, Razak IA, Rahman SA, Borromeo GL. Educating medical students in oral health care: current curriculum and future needs of institutions in Malaysia and Australia. Eur J Dent Educ 2017;21:e29-e38.

18.Rodakowska E, Kierklo A, Jamiołkowski J. Selfreported oral health behaviour among Scandinavian and Polish medical students studying in Poland. Cent Eur J Public Health 2016;24:68-75.

19. Nicely SL. Effects of a comprehensive oral health curriculum on knowledge, behavior, and attitude of physician assistant students. J Physician Assist Educ 2016;27:73-6.

20.Abbott B, Zybutz C, Scott KM, Eberhard J, Widmer $R$. A review of the hours dedicated to oral health education in medical programmes across Australia. Intern Med J 2018;48:1035-40.

21.Kumar H, Behura SS, Ramachandra S, Nishat R, Dash KC, Mohiddin G. Oral health knowledge, attitude, and practices among dental and medical students in eastern India - a comparative study. J Int Soc Prev Community Dent 2017;7:58-63.

22.Park SE, Donoff RB, Saldana F. The impact of integrating oral health education into a medical curriculum. Med Princ Pract 2017;26:61-5.

23.Koşan Z, Akgül N, Bedir B, Çalıkoğlu EO, Yılmaz S, Derelioğlu SŞ. Tıp ve diş hekimliği fakültelerinde ağız - diş sağlığı eğitimi yeterli mi? Öğrencilerin bilgi düzeylerinin karşılaştırması. Turk J Public Health 2017;15:201-11.

\section{Yazışma Adresi}

Dr. Öğr. Üyesi Gökhan Özkan, ADÜ Diş Hek. Fak.

Ağız, Diş ve Çene Radyolojisi A.D.

Aydın/Türkiye

Tel. 05065009470

e-mail: asgokhanozkanus@hotmail.com 